\title{
PERANAN RESEPSIONIS \\ PADA PT MOGEMS PUTRI INTERNATIONAL \\ JAKARTA
}

\author{
Oleh : Edi Junaedi, SE., MM. dan Sifailah Fauziah
}

Dosen Prodi Sekretari Universitas Pamulang

\section{Junaedisalat1@yahoo.com}

\begin{abstract}
Abstrak
Seorang resepsionis di sebuah perusahaan harus mempunyai etika komunikasi yang baik dan benar, baik komunikasi lisan maupun tulisan, sehingga orang lain atau tamu dapat mengerti dan memahami apa yang disampaikan oleh seorang resepsionis. Mengikuti dan menguasai setiap SOP di perusahaan khususnya dalam hal pekerjaan yang menjadi tanggung jawabnya setiap hari.
\end{abstract}

Kata Kunci : Peranan Resepsionis

\section{PENDAHULUAN}

\section{A. Latar Belakang Masalah}

Resepsionis adalah orang yang bertugas sebagai penerima tamu disuatu perusahaan. Pada mulanya resepsionis bertanggung jawab hanya untuk tugas seperti menjawab panggilan telepon, dan meneruskan panggilan tersebut untuk masing-masing departemen, menerima dan mengirim email, mengurus surat menyurat, dan melayani tamu sesuai kebutuhan mereka. Zaman sekarang ini, dengan perkembangan teknologi dan berkembangnya ruang lingkup perusahaan, maka tugas resepsionis telah mengalami perubahaan yang luar biasa.

Citra perusahaan juga ditentukan oleh resepsionis, meskipun juga banyak faktor lainnya, tapi setidaknya orang melihat perusahaan dan berkomunikasi dengan perusahaan pertama melalui resepsionis. Resepsionis bukan Cuma berwajah cantik, tubuh tinggi semampai, tetapi juga pengetahuan, sikap yang matang dan perilaku yang baik dan benar. Berdasarkan latar belakang yang ada, penulis mengambil judul "Peranan Resepsionis pada PT Mogems Putri Internasional Jakarta”. 


\section{B. Identifikasi Masalah}

Berdasarkan latar belakang tersebut diatas, maka penulis mengidentifikasi masalah sebagai berikut :

1. Peranan Resepsionis PT Mogems Putri Internasional Jakarta

2. Hambatan Resepsionis dalam melaksanakan tugas pada PT Mogems Putri Internasional Jakarta

\section{Perumusan Masalah}

Berdasarkan identifikasi masalah diatas, maka penulis merumuskan masalah sebagai berikut:

1. Apa saja peranan Resepsionis PT Mogems Putri Internasional Jakarta?

2. Hambatan apa saja yang dihadapi Resepsionis dalam melaksanakan tugas pada PT Mogems Putri Internasional Jakarta?

\section{PEMBAHASAN DAN HASIL}

\section{A. Pengertian Resepsionis}

Resepsionis adalah orang yang bertugas sebagai penerima tamu disuatu perusahaan, kantor, hotel. Sebagai seorang resepsionis harus memiliki antara lain : kepribadian yang manarik, penampilan yang mempesona, kerapian yang serasi, keramahan, kepandaian, sikap sopan santun dan sabar.

\section{B. Tugas-Tugas Resepsionis}

Peran seorang resepsionis di sebuah perusahaan sangatlah penting, biasanya resepsionis berada di depan sebuah perusahaan. Adapun tugas-tugas resepsionis sebagai berikut :

1. Menerima dan menjawab telepon serta mencatat pesan-pesan telepon

2. Menerima dan menjawab email

3. Menerima tamu yang akan bertemu dengan pimpinan

4. Mencatat janji-janji untuk pimpinan

5. Menyusun acara kerja sehari-hari pimpinan 
6. Menerima surat masuk/surat yang datang untuk pimpinan dan karyawan di perusahaan. 7. Membantu tugas administrasi

\section{Etika Komunikasi}

Etika komunikasi adalah penyampaian pesan atau berita antara komunikator dengan komunikan dengan memperhatikan perilaku, sikap yang baik dan yang tidak baik, untuk dilakukan ketika berkomunikasi.

\section{Pengelolaan Telepon Masuk dan Keluar}

\section{Respons untuk menerima telepon (incoming calls)}

a. Mengangkat gagang telepon dengan menggunakan tangan kiri, sementara tangan kanan memegang alat tulis serta kertas berisi lembaran pesan telepon yang biasa tersedia untuk mencatat hal yang penting

b. Menyampaikan salam seperti selamat pagi, siang atau sore menyapa penelepon dengan sebutan Ibu/Bapak/Saudara,

c. Menyebutkan identitas diri, kantor, atau perusahaan

d. Mencatat hal-hal penting dalam lembar pesan telepon

e. Bila penelepon kurang jelas, jangan sampai menyebutkan kata apa, hah, heh, karena hal itu tidak sopan, sebaiknya mohon kepada penelepon agar mengulangi lagi maksudnya atau kita sendiri mengulang kembali maksudnya (informasinya)

f. Jika penelepon belum memberitahukan identitasnya, mintalah agar penelepon menyebutkan identitas dengan jelas dan nomor telepon yang dapat dihubungi

\section{Melakukan panggilan keluar (outgoing calls)}

a. Persiapan menelepon

Siapkan nomor telepon yang hendak dituju, perhatikan bahwa nomor telepon sudah tepat, siapkan peralatan menulis berupa kertas dan pulpen, catatlah hal-hal pokok yang akan disampaikan kepada pihak yang dituju.

b. Cara menangani telepon keluar

1) Angkat gagang telepon pesawat telepon dan tekan nomor telepon yang akan dituju sedang sibuk, letakkan gagang pesawat telepon dengan pelan dan hatihati. Tunggu sejenak, kemudian telepon kembali 
2) Apabila ada nada sambung dan telepon yang dituju sudah ada jawaban, maka katakan selamat pagi/siang/sore, sebutkan nama perusahaan dan nomor telepon yang dituju untuk meyankinkan bahwa tidak salah sambung.

3) Jika salah sambung, hendaknya meminta maaf

4) Apabila berhasil berbicara dengan orang yang dimaksud perkenalkan diri dan nyatakan maksud menelepon

5) Akhiri pembicaraan dengan ucapan terima kasih dan salam

6) Letakkan gagang telepon dengan hati-hati dan benar.

\section{Etika Menelepon}

a. Jangan sekali-kali membicarakan informasi rahasia di telepon. Sistem telepon yang kurang bagus memungkinkan pembicaraan Anda terdengar oleh orang lain, bahkan kadang-kadang ada orang lain yang sengaja ikut mendengarkan pembicaraan Anda.

b. Jangan berbicara terlalu keras, atur suara Anda sebab pembicaraan yang terlalu keraas akan mengganggu rekan kerja atau pimpinan Anda.

c. Jangan berbicara dengan orang ketiga selagi Anda menelpon, suara orang ketiga tersebut mungkin terdengar di seberang dan ini tidak sopan.

d. Batasi pembicaraan telepon pribadi di kantor.

\section{Hambatan-Hambatan dalam Bertelepon}

Ada 2 (dua) faktor penghambat ketika bertelepon, yaitu:

a. Faktor Alat

Maksudnya hambatan terjadi karena peralatan telepon tidak berfungsi dengan baik. Hal seperti ini dapat berupa: suara berisik, suara timbul tenggelam, suara mengecil, tidak terdengar nada kontak, nada sambung tidak terdengar, atau sambungan terputus ketika berbicara.

b. Faktor Pengguna Telepon

Maksudnya orang yang menggunakan telepon maupun penelepon bersikap kurang baik. Misalnya berbicara sambil makan, meninggalkan telepon sambil berbicara kepada orang lain atau berbicara kepada pihak ketiga, desah napas keras, berbicara kurang baik atau kotor, sambil bersenda gurau yang keterlaluan, berbicara dengan kepala bergerak ke kanan dan ke kiri, atau letak gagang telepon ketika berbicara terlalu ke atas atau ke bawah. 


\section{E. Penerimaan Tamu}

Kata tamu dalam kamus bahasa indonesia dapat berarti orang yang datang berkunjung ke tempat orang lain atau orang yang datang ke perjamuan. Menurut Wursanto (2006:55), Tamu adalah tamu organisasi, badan, lembaga, atau perusahaan, yaitu orang, baik sebagai pejabat utusan dari suatu lembaga maupun sebagai pribadi, yang berkunjung ke lembaga lain untuk kepentingan kedinasan, maupun untuk kepentingan pribadi.

\section{Macam-Macam Tamu}

1. Tamu dengan perjanjian

2. Tamu tanpa perjanjian

3. Jenis tamu yang dapat diterima pimpinan

\section{F. Penerimaan Surat Masuk}

Pengertian surat adalah sarana komunikasi untuk menyampaikan informasi tertulis oleh suatu pihak kepada pihak lain.

Langkah - langkah penerimaan surat masuk, antara lain:

1. Menerima jasa pelayanan pengiriman (kurir) dengan sopan dan ramah

2. Mengecek surat yang datang (masuk), berdasarkan asal surat atau pengirim,

3. Mengecek cara pengiriman,

4. Mengecek nama perusahaan apa sudah sesuai dengan perusahaan tempat kita bekerja

5. Mengecek tanda-tanda khusus,seperti tulisan tangan, cap/stempel rahasia, urgent, private and confidential

6. Mencatat surat yang datang (masuk) ke buku surat masuk

7. Menyortir atau mengklasifikasikan surat masuk sesuai dengan alamat dan contact person yang dituju

8. Mendistribusikan atau memberikan langsung surat masuk tersebut kepada departemen yang dituju atau kepada Sekretaris pimpinan perusahaan.

PT Mogems Putri International selaku perusahaan yang bergerak dibidang perdagangan, selalu bekerjasama dengan berbagai macam vendor atau perusahaan lain. Oleh sebab itu maka banyak tamu yang sering berkunjung ke perusahaan, maka dibutuhkan seorang resepsionis untuk melayani tamu tersebut. Adapun Pekerjaan yang dilakukan oleh seorang resepsionis pada PT Mogems Putri International antara lain : 
1. Menerima tamu yang datang ke Perusahaan

Dalam penerimaan tamu seorang resepsionis harus menyambut tamu dengan sopan, dan mengisi buku tamu yang sudah disediakan oleh perusahaan.

2. Menerima telepon masuk serta mencatat pesan telepon

Dalam penerimaan telepon masuk, resepsionis menjawab dengan menyebutkan salam, lalu nama perusahaan, nama resepsionis, menanyakan nama dan keperluan penelpon, menyambungkan telepon tersebut kepada orang yang dituju, dan jika orang yang dituju tidak ditempat berikan alasan yang masuk akal, serta mencatat pesan telepon.

3. Menerima dan membalas E-mail

Seorang resepsionis setiap hari harus mengecek email yang masuk, baik email yang masuk dari internal perusahaan maupun eksternal perusahaan contohnya email dari vendor. Dalam membalas email yang masuk dengan menggunakan kata-kata yang sopan dan jelas.

4. Pengelolaan telepon keluar

Pengelolaan telepon keluar yaitu resepsionis membantu karyawan dan pimpinan untuk menelpon keluar kota. Menggunakan kode daerah atau kota yang ingin dituju.

5. Menerima surat masuk, dokumen, bingkisan/paket untuk diserahkan kepada karyawan perusahaan, Sekretaris, dan pimpinan

Penerimaan surat masuk, dokumen, bingkisan/paket yang datang ke perusahaan, sebelum menerimanya resepsionis harus menandatangani tanda terima yang sudah disediakan oleh kurir dengan memberi nama jelas serta tanggal terima.

6. Pencatatan penerimaan surat masuk, dokumen, bingkisan/paket yang datang ke perusahaan.

7. Setelah surat masuk, dokumen, bingkisan/paket diterima, maka resepsionis mencatat pada buku surat masuk yang sudah disediakan perusahaan.

8. Membantu administrasi HRD dalam hal data hadir karyawan, fotocopy dan lain-lain.

Resepsionis membantu administrasi HRD yaitu dengan mengumpulkan form lembur karyawan, setelah terkumpul lalu diserahkan ke Staf HRD, menginfokan karyawan yang tidak masuk dengan sebab ijin, atau sakit, menyimpan dan memberikan form-form terkait dengan karyawan seperti: form cuti, cek in cek out, ijin,form interview calon karyawan dan lain-lain kepada karyawan yang membutuhkan, membantu fotocopy surat-surat HRD, membantu scan surat. 
Dalam kegiatan sehari-hari seorang resepsionis mendapatkan hasil yang diperoleh yaitu ilmu, baik itu teori maupun praktek dalam pelaksanaan pekerjaan sehari-hari sebagai resepsionis perusahaan. Menambah pengalaman dalam bekerja khususnya pada bidang resepsionis, serta mempunyai banyak teman dan relasi dalam bekerja.

Pada PT Mogems Putri International peranan seorang resepsionis sangatlah penting karena, citra perusahaan juga ditentukan oleh seorang resepsionis. Jika ada telepon masuk, penerimaan tamu, penerimaan surat masuk maka seorang resepsionis mempunyai tanggung jawab untuk menerima itu semua. Sikap dan tindakan yang baik, sopan serta pandai akan mempengaruhi kinerjanya.

Dalam pekerjaannya seorang resepsionis juga mengalami hambatan-hambatan.

Berikut ini hambatan-hambatan yang sering terjadi pada resepsionis :

1. Penelpon tidak jelas menyebutkan nama $\&$ jabatan untuk orang yang dituju

2. Suara penelpon terlalu bising, terputus-putus

3. Ada gangguan pada pesawat telepon perusahaan

4. Pada saat penerimaan surat masuk atau paket berupa bingkisan, nama dan alamat yang dituju tidak jelas atau kurang lengkap.

\section{KESIMPULAN}

Resepsionis adalah orang yang bertugas sebagai penerima tamu disuatu perusahaan, kantor, hotel dan lain-lain. Seorang resepsionis harus memiliki kompetensi antara lain : kepribadian yang manarik, penampilan yang mempesona, kerapian yang serasi, keramahan, kepandaian, sikap sopan santun dan sabar.

Tugas seorang resepsionis pada PT Mogems Putri International yaitu menerima tamu yang datang ke perusahaan, menerima dan menjawab telepon serta mencatat pesan telepon, menerima dan menjawab e-mail, pengelolaan telepon keluar, menerima surat masuk, dokumen, bingkisan/paket untuk diserahkan kepada karyawan perusahaan atau pimpinan, melakukan pencatatan penerimaan surat masuk, dokumen, bingkisan/paket yang datang ke perusahaan, membantu administrasi HRD dalam hal data hadir karyawan, fotocopy. Resepsionis harus mempunyai etika dalam pekerjaannya, adapun etika mempunyai arti ilmu pengetahuan tentang asas akhlak dan moral.

Dalam pekerjaannya seorang resepsionis juga mengalami hambatan-hambatan, diantaranya : Penelpon tidak jelas menyebutkan nama $\&$ jabatan untuk orang yang dituju, 
Suara penelpon terlalu bising, terputus-putus, ada gangguan pada pesawat telepon perusahaan dan pada saat penerimaan surat masuk atau paket berupa bingkisan, nama dan alamat yang dituju tidak jelas atau kurang lengkap.

\section{DAFTAR PUSTAKA}

Dewi, Yuniasari Shinta, “Bekerja Sebagai Sekretaris”, Penerbit Erlangga, Jakarta, 2011.

Dwiantara, Lukas, “Sekretaris Profesional”, Penerbit Kanisius, Yogyakarta, 2000.

Hendarto, M.G.Hartiti, “Menjadi Sekretaris Profesional”, Penerbit PPM, Jakarta, 2008.

Honiatri, Euis, "Mengaplikasikan Keterampilan Dasar Komunikasi”, penerbit Pustaka Setia, Jakarta, 2009.

Kadarmo, Siwi, "Sekretaris Dan Tugas-Tugasnya”, Cetakan kelima, Penerbit Nina Dinamika, Jakarta, 2001.

Nuraeni, Nani, "Panduan Menjadi Sekretaris Profesional", Penerbit Visi Media, Jakarta, 2008. 